\title{
Afterword: "I Am the River, and the River Is Me"
}

\section{Dame Anne Salmond}

\begin{abstract}
In Aotearoa New Zealand, with the passage of the Te Awa Tupua (Whanganui River Claims Settlement) Act in 2017, the Whanganui River was recognized as a legal person, with its own life and rights. At the same time, an inextricable relationship between the river and Whanganui Māori kin groups was acknowledged when a group known as Te Pou Tupua was legally established as "the human face" of the river, an agency that speaks for it and acts on its behalf (Salmond 20I4; 20I7, 29I-3 I 5; New Zealand Government 2017).

With the passage of this pioneering legislation, the legal framework in Aotearoa New Zealand was stretched in an effort to accommodate the living presence of ancestors in the landscape and their existential interlock with their human descendants. The act was passed along with an apology from the Crown for long-term damage to the river. As Huhana Smith explains in her article in this special issue, "the effects of intensified dairying, coastal dune pine tree forestry, and expanding inland market gardens have resulted in accumulated impacts on the health of freshwater springs and tributaries that ... join major waterways" (this issue, 22), and many rivers across Aotearoa New Zealand, including the Whanganui, have been severely degraded. As one Whanganui elder lamented in front of the tribunal when their Treaty of Waitangi claim was lodged: "It was with huge sadness that we observed dead tuna [eels] and trout along the banks of our awa tupua [ancestral river]. The only thing that is in a state of growth is the algae and slime. Our river is stagnant and dying. The great river flows from the gathering of mountains to the sea. I am the river, the river is me. If I am the river and the river is me-then emphatically, I am dying." ${ }^{1}$

In an effort to express the entanglement between Whanganui genealogical lines and the currents of the river, as well as the life force (mauri, hau)
\end{abstract}

The Contemporary Pacific, Volume 32, Number I, I64-I7I

(C) 2020 by University of Hawai' $i$ Press 
of the river and its people, the Te Awa Tupua Act includes a preamble in te reo Māori:

Ko te Awa te mātāpuna o te ora

The river is the source of ora (a state of health and well-being)

E rere kau mai i te Awa nui mai i te Kähui Maunga ki Tangaroa

The great river runs freely from the gathering of mountains to Tangaroa

(the sea)

Ko au te Awa, ko te Awa ko an

I am the river, and the river is me. ${ }^{2}$

In this kin-based world, where land, sea, and waterways are more ancient and powerful than people, culture and nature are not divided, nor are people and environment, mind and matter, subject and object. Rivers, fish, whales, birds, mountains, and the ocean can be ancestors, sharing the same descent lines as human beings, and ancestors participate in everyday life with their descendants. Indeed, some descendants may be the "living faces" of their ancestors, speaking with their voices. If the river, their source of life, is harmed, the life force of the people is also damaged.

In a way that resonates with the framing of the Te Awa Tupua Act, Myjolynne Kim opens her chapter with a greeting from Micronesia in the Chuukese language:

Tirow Nang (I bow to the Heavens)

Tirow Fénú (I bow to the Land)

Tirow Mataw (I bow to the Seas)

Tirow Aramas, Tirow (I bow to the People).

In Chuukese ancestral ways of being, she explains, "the environment is life and connects humans, nonhuman, and spirit beings. It encompasses nááng (skies), mataw (ocean), and fénú (land) and is esteemed as manaman (sacred), alive, and motherly. The environment bears life just as a woman bears life. In Chuukese ontology and structures of feeling we are all connected through maternal creation. As mothers, women embody the environment, making visible in human domains its broader role in giving birth to all living things, human and nonhuman, spirits and non-spirits" (Kim, this issue, I47).

Just as the Chuuk archipelago was exposed to the influence of four successive imperial nations-Spain, Germany, Japan, and the United Statesand Christian missionaries, the underlying relationship between women 
as mothers and the living world in this matrilineal society was disrupted by impositions of masculine power. As the power of women in Chuuk and other Micronesian archipelagos has been diminished, the living world around them has been degraded by the impacts of colonization, militarization, nuclear testing, phosphate mining, and now climate change. Kim concludes, "To contaminate and destroy the environment is to degrade women and undermine their potency and fundamental position in society" (this issue, I 59) — and vice versa, one might add.

In his article, too, Michael Mel points out how among Mogei people in Papua New Guinea, this embodied kind of relationality fundamentally shifts the nature of personhood and the relations between people and environment:

In many Western perspectives, the world and human beings form a dichotomy: the world is separate from the person, and the person makes sense of the world. This enables people to construct and impose meaning. In the Mogei context, an individual's capacity to live and work is referred to as nanga noman. Nanga noman relates to an individual's feelings, thoughts, interests, fears, knowledge, and desire, and it is only realized through the idea of $m b u$. Mbu is the living relationship between a person and the world-a tripartite relationship between pulg wamp (all people living and dead), mbu wamp (individuals in a family and within a community), and maei mbu (the physical environment and all things around us). (this issue, 52-53)

Since world and people are not separated in Mogei ancestral thinking, and people are not detached spectators who comment and act on the world, relations with ancestors, ancestral territories, other people, and living beings are constitutive, making people who they are-deeply entangled with kin groups and ancestral landscapes, defined by their participation in dynamic patterns of exchange within these living systems.

These embodied relations may be literally planted in the land, as Nicholas Evans describes for Nen-speaking people in southern New Guinea, where "one form of other-than-human entity-the coconut palm-is used to create and maintain memories, including memories of intentions and pledges for the future, thus creating a link between a human and a growing, nonhuman element of the landscape from the moment it is planted" (this issue, 73). This kind of framing, however, clashes with modernist understandings in which people and environment, mind and matter, subject and object are fundamentally split and time is linear, 
an arrow that flies from the past into the future, leaving the past (and ancestors) behind. Here it is not possible to have direct exchanges with ancestors, nor for them to take part in everyday affairs. As a result, accounts may be devised that convert these relationships into "just-so" stories about animism, anthropomorphism, totemism, and the like in which mind versus matter, subject versus object, people versus environment, culture versus nature, and past versus present dichotomies survive unchallenged, even when describing living worlds in which these divisions do not apply.

This kind of ontological refusal has many practical effects. As Deborah Gewertz and Frederick Errington eloquently describe in their article on Chambri cosmology, faced with disbelief in the power of ancestors from missionaries and others, many of those who formerly used their relations with ancestors to influence land, water, and fish on behalf of the community ceased to do this, while others saw such powers as an opportunity to make money, so that "the environment of environmental control significantly shifted as the regulation of the winds, water, and fish moved from a cosmological division of labor to a for-profit, 'business' enterprise" (this issue, I40). Young people began to define themselves in ways that defied ancestral conventions, losing interest in acquiring ancestral knowledge and instead exploring Christian alternatives. In Chambri, collective relations with their ancestral lake were disrupted, a new species of fish was introduced that disturbed the local ecosystem, and Chambri Lake became unpredictable and unruly.

In the case of the Kuwae eruption in Vanuatu, discussed by Chris Ballard in his article, narratives describing this as a cataclysm caused by the fury of the ancestor Tombuku, who had been tricked into sleeping with his widowed mother, were told in stripped-down versions to the first Presbyterian missionaries and European administrators on the island. Ballard quotes R E N Smith of the British administration as recalling that "in our wisdom, we had been inclined to discount New Hebridean tales of this event and how Tongoa had had only one man and one woman survivor; perhaps we thought it some sort of creation myth" (this issue, I05). This kind of skepticism, which labels stories that presuppose the power of ancestors to shape the world as "myth" or "superstition," has been commonplace in Oceania, leading to accounts in which their validity is already discounted. Not surprisingly, the versions told to such interlocutors are often relatively impoverished. Instead of seeking to explore a world in 
which ancestors can provoke an eruption, the stories of Kuwae may be displaced by scientific narratives that use ancestral stories as "clues" to help to construct more "reliable" accounts.

Mel, too, explores the effects of assumptions of ontological superiority in Western practices of collecting and museums, which assume that ancestral works are "artifacts" or "objects" for detached study and inspection, handled with gloves, displayed in glass cases, and held in storage spaces. Here, he argues, divisions between mind and matter, animate and inanimate, subject and object are taken for granted, and the world is fractured in ways that make little sense for the creators of such works and their descendants. Mel describes performances that he curated in museums to dispute such assumptions, partly by using satire and evoking ancestral spaces and partly by turning spectators into participants: "Come, ladies and gentlemen, to the world of the native. Located here for all to see, framed and captured. Come and see for yourselves the specimen of a native. Never seen before. Now made present before your very eyes. But, ladies and gentlemen, we should allow the native to sing, dance, and perform for us. Come and help decorate her, and she will perform. Who wants to decorate her? Please ... yes, thank you, up you come" (this issue, 60).

Such ontological uprisings, reasserting embodied relations between people and the living world, are also explored by Kim in her discussion of Chuukese ways of life, where the female ancestor Nikoupwupw Fénú, bearer of the islands, assumed the form of a coconut tree and gave birth to the islands, the people, and all its creatures. Female ancestors have always been powerful in this region, and Kim describes how Micronesian women have been at the forefront of efforts to protect their islands and seas from environmental devastation. She cites the work of women like Darlene Keju-Johnson from the Marshall Islands, who led the struggle against nuclear testing in the islands; Gabriela Ngirmang Mirair, who fought for a nuclear-free Palau; and Chailang Palacios, a female activist from Guåhan, whom she quotes as saying, "We are the people of the land and the ocean and we are struggling for survival. The ocean is our spirit. We come back, we sit down, we cry, we pray, we are still praying. Because our water is killing us, slowly. It has been polluted since World War II and since the nuclear bombs" (Kim, this issue, I 56 ).

The revival of Oceanic voyaging, led by the Micronesian navigator Mau Piailug and his students across the Pacific, is another instance of Pacific Islanders reasserting deep ancestral relations between people and the ocean, while disputing the virtues of industrial capitalism. Here, 
mind-matter splits that underpin the commodification and devastation of oceanic spaces and marine creatures and the culture-nature division that detaches people from the living systems that sustain them, obscuring their own impacts on them and the implications for their own survival, are challenged. At present, the voyaging community in Aotearoa New Zealand is considering ways of reasserting the power of Hinemoana (the Pacific Ocean) as an ancestral being with her own life and rights to health and well-being, building on the legal precedents set by the Whanganui River and the Urewera territory of Tùhoe people.

In Aotearoa New Zealand, where the Treaty of Waitangi has been built (if imperfectly) into the Resource Management Act, as Smith describes in depth and detail, collaborative efforts between scientists and Māori kin groups to restore degraded environments are happening in many parts of the country. Smith herself is a pioneering leader, establishing a series of restorative projects in the Horowhenua region in the southwest of North Island, and showing others how to make such collaborations work. Ancestral ideas about collective responsibility and working together to uphold the treaty inspired her to bring together teams of scientists and local communities in shared projects to restore ora to degraded waterways and coastal environments. In one project, as she notes, the team included "an archaeoseismologist, a coastal processes expert, terrestrial and coastal freshwater ecologists, a hydroecologist, ecological economists, landscape architects, ... and tidal marine scientists," while in a more recent project focused on climate change, "the group comprised local Māori researchers, artists, landscape architects, 2-D and 3-D designers, a fluvial geomorphologist, a climate change scientist, and senior MA students" (Smith, this issue, 24).

Like Mel, Smith uses exhibitions and artistic practice as well as cuttingedge science to communicate with wide audiences. Like mind-matter divisions, mind-heart splits do not apply in Oceanic environments, nor do divisions between theory and practice or between the natural sciences and the arts and humanities-and in any case, such radical polarities have been rendered obsolete by the findings of contemporary science, including neuroscience, quantum physics, and the life and environmental sciences. These experiments are creative, bridging gaps of understanding, displacing old, outmoded dichotomies, and seeking to reclaim Oceanic ways of living in Oceanic worlds. Contrary to the claim often made in anthropological debates that a turn toward ontological inquiry is invariably neocolonial and repressive (Todd 20I6), these initiatives are empowering-as 
one can also see from the projects aimed at recognizing the rights of the Whanganui River and of Hinemoana to ora.

These are gifts, and as Sina Emde, Eveline Dürr, and Philipp Schorch say in their thoughtful introduction to this special issue, "In the maritime spaces of Oceania, relations and gift exchanges connect islands and travel across the sea while simultaneously affirming belonging and claims to land and place" (7). In an ocean that is being ravaged by pollution and rubbish, overfishing, rising seas, dying coral reefs, and drowning islands, the deep roots of this dysfunction need to be examined and alternative ways of thinking and being discovered. Anthropologically grounded, cross-disciplinary inquiries could and should be part of this enterprise. As this special issue demonstrates, in Oceania-and fortunately for us all-that work is already underway.

\section{Notes}

I Tiirama Thomas Hawira, quoted in Waitangi Tribunal I999, 56.

2 New Zealand Government 2017, subpart 2, clause I3.

\section{References}

New Zealand Government

20I7 Te Awa Tupua (Whanganui River Claims Settlement) Act 20I7. Available from: http://www.legislation.govt.nz/act/public/2017/0007/ latest/whole.html [accessed 5 June 20I9]

Salmond, Anne

2014 Tears of Rangi: Water, Power, and People in New Zealand. HAU: Journal of Ethnographic Theory 4 (3): 285-309.

2017 Tears of Rangi: Experiments across Worlds. Auckland: Auckland University Press.

Todd, Zoe

2016 An Indigenous Feminist's Take on the Ontological Turn: "Ontology” Is Just Another Word for Colonialism. Journal of Historical Sociology 29:4-22.

Waitangi Tribunal

I999 Whanganui River Report. Wai I67. Wellington: GP Publications. Available from: https:/forms.justice.govt.nz/search/Documents/WT/ wt_DOC_68450539/Whanganui\%20River\%20Report\%201999. pdf [accessed 5 June 20I9] 


\section{Abstract}

"I Am the River, and the River Is Me," the afterword to this special issue, weaves together a series of creative experiments across the Pacific that seek to displace old, outmoded dichotomies and reclaim Oceanic ways of living in Oceanic worlds. Across Oceania, many modernist assumptions are being disputed, as Huhana Smith describes for Aotearoa New Zealand, Michael Mel for Mogei people in Papua New Guinea, and Nicholas Evans for Nen-speaking people in southern New Guinea. In the past, “just-so” stories about animism, anthropomorphism, totemism, and the like in Oceania proliferated in which these divisions survived unchallenged, even when describing living worlds in which they do not apply. Such ontological refusals have impoverished our understandings, as Chris Ballard recounts for the Kuwei eruption in Vanuatu, and when local people adopt them, they fundamentally disrupt their ways of living, as Deborah Gewertz and Frederick Errington describe for Chambri in Papua New Guinea. An ontological uprising is occurring across Oceania as ancestral ways of relational thinking are being reasserted, as Myjolynne Kim explores in her account of women in Chuuk and elsewhere in Micronesia. As the Pacific Ocean is being ravaged by pollution and rubbish, overfishing, rising seas, dying coral reefs, and drowning islands, alternative ways of thinking about relations among people and between people and other life-forms are urgently needed. Scholarly inquiry should be part of this enterprise, and as this special issue demonstrates, in Oceania-and fortunately for us all-such work is already underway.

KEYWORDs: Whanganui River, Pacific environments, ontologies, dichotomies, environmental well-being, environmental change 